\title{
Visual Hazards of Social Media Users among University Students in Dhaka City: A Comparison between Public and Private Universities
}

Md. Ruhul Amin ${ }^{1 *}$

Khaleda Islam²

\author{
'PhD Researcher \\ Centre for Higher Studies and Research \\ Bangladesh University of Professionals \\ Dhaka, Bangladesh. \\ ${ }^{2}$ Professor \\ Institute of Nutrition and Food Science \\ University of Dhaka, Bangladesh.
}

\begin{abstract}
Background: Intensive use of social media threat to physical health, visual disorders is one them. A cross-sectional analytical study was conducted to identify the visual hazards of social media users among students of public and private universities in Dhaka city.

Materials and methods: A pretested, semi-structured standard questionnaire and randomized sampling technique was used to collect the data, the number of calculated sample size was 726.

Results: Study revealed that mean age of the respondents of public university were 21.551.93 years and private university were 21.141 .62 years. It was found that $28.10 \%, 9.90 \%, 17.90 \%, 10.70 \%, 6.60 \%, 22.60 \%, 8.50 \%, 0.60 \%, 18.70 \%, 2.80 \%$, $1.90 \%, 2.80 \%$ and $0.60 \%$ of the respondents of public university complained headache, dry eye syndrome, eye strain, burning, itching, tearing eyes, irritated eyes, squinting, blurry vision, double vision, temporary change in color vision, trouble seeing at night, distorted vision respectively and that of the students of private university were $36.60 \%, 9.60 \%, 22.00 \%, 12.70 \%, 11.80 \%, 31.70 \%, 14.90 \%, 5.50 \%, 15.70 \%$, $6.90 \%, 6.30 \%, 6.10 \%$ and $0.80 \%$ respectively. Social media disorders influence significantly on eyestrain of the students of both public and private universities.
\end{abstract}

Conclusion: Social media had different types of visual hazards among the students of both public and private universities in Dhaka city.

Key words: Social media; Social media disorders; Visual hazards.

\section{INTRODUCTION}

Today, information and communication technologies have become an integral part of our lives. Many people, especially adolescents, spend most of their time studying, searching for information on the internet, playing games and communicating with technical tools. Social media is a variety of internet-based networks that enable users to communicate with others verbally and visually. Social media such as modern online technology has been growing over the last decade. Although this technology has been associated with many positive qualities such as entertainment, business benefits, cognitive skills development, social capital and social interaction. Concerns have been raised about overuse, in particular, as users are more likely to be addicted to the use of such technology. In this context of addictive use, overly concerned about online activities, and consumes spend so much time and effort that it hinders other important areas of life. There are various negative consequences through social media in both adolescents and adults. The excessive use of social media causes threat to the physical and mental health of the user, visual problem is one of them.

Digital devices usages increased in recent years of all age group, so that extensive uses of devices fall in digital eye strain. The prevalence of digital eye strain was fifty percent or more among users whereas symptoms were main two categories, one of 
the binocular vision stress and dry eye ${ }^{1}$. More common vision syndrome were headache, eye strain, double vision, dry eyes and eye fatigue whereas the risk factors of the computer vision syndromes were individual visual problems and poor ergonomics $^{2}$. Extensive viewings of the computer screen lead to eye discomfort, fatigue, blurred vision, headache, dry eye and eye strain. These symptoms may cause poor lighting, glair, improper setting of work station whereas these symptoms may susceptible to adult ${ }^{3}$.

Indian urban students age 11-17 years students who preferred lie down those who experienced eyestrain. Among the respondents $18 \%$ of the users complained eyestrain at the end of the day after working digital devices ${ }^{4}$. Chukyo University students, aged 18-23 years, uses of mobile phone produce visual hazards and cognitive impairment ${ }^{5}$. Among young college students, aged $18-25,73 \%$ used white screen, $70 \%$ used black screen and $66 \%$ viewing radius was more than $25 \mathrm{~cm}$ whereas $80 \%$ of the students used smart phone 2 hours per day causes develop visual symptoms ${ }^{6}$.

Headache complains were higher in the high smart phone users $^{7}$. Visual hazards of software professional were $67 \%$, musculoskeletal disorders were $63 \%$ and stress were $44 \%$. Visual and musculoskeletal disorders were positively correlated to digital devises ${ }^{8}$. Call centers operators in Sao Paulo, Brazil eye fatigue were $73.9 \%$, weighty eye were $68.2 \%$, burning were $54.6 \%$, tearing were $43.9 \%$ and weakening of vision were $43.5 \%$ whereas the prevalence of computer vision syndrome was $54.6 \%$ and effects of visual fields among adult cell phone users $^{9-11}$.

\section{MATERIALS AND METHODS}

A cross-sectional analytical study was conducted to explore the visual hazards of social media among university students of public and private university in Dhaka city with 726 . This study sites in Dhaka University and Daffodil International University. A pretested, semi structured questionnaire was used to collect the data on the basis of objective and variables. Data were collected from Hazi Muhammad Mohsin Hall, Fazlul Huq Hall, Jagannath Hall and Ruquyyah Hall from Dhaka University. Whereas the students of Daffodil International University participate the study from different faculty of their academic campus including Faculty of Health Science, Faculty of Business Studies, Facility of Social Science, Faculty of Humanities, Faculty of Engineering. Data were collected from students of $2^{\text {nd }}$ year $/ 3^{\text {rd }}$ semester and above. After collection of data, it was checked and rechecked with competently. The data were analyzed by using Statistical Packages for Social Sciences (SPSS) software, version 20. After analyzed the data set all findings were interpreted by tabulated form. Univariate, bivariate, multivariate analysis were done and diagram were prepared by use of SPSS and Microsoft Office Excel.

\section{RESULTS}

Table I : Distribution of respondents by socio-demographic variables $(n=726)$.

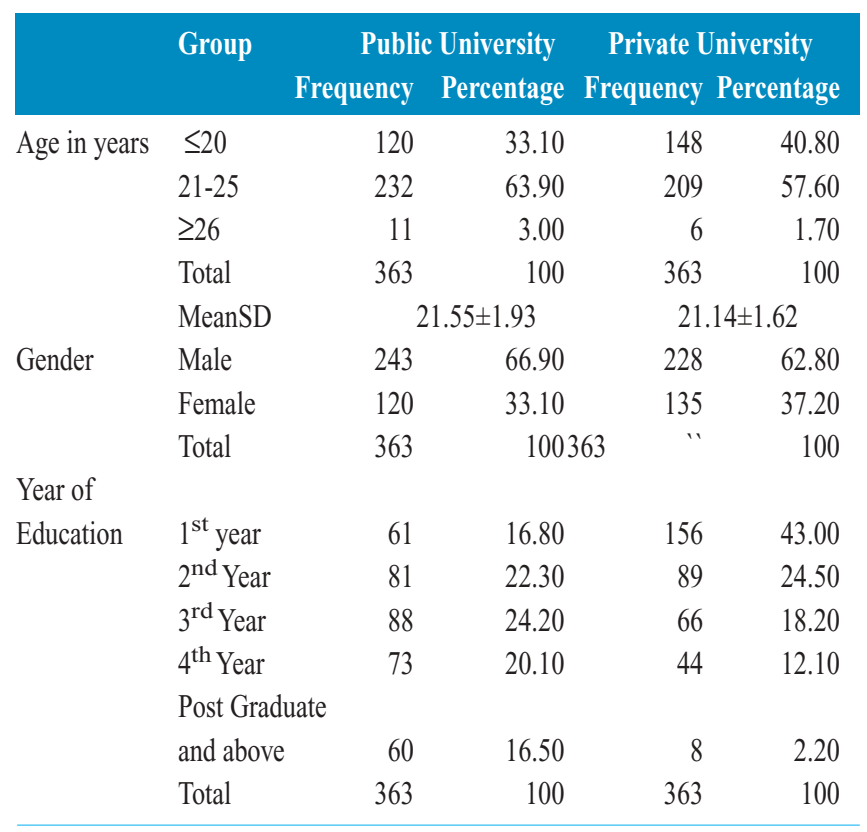

Table I shows that $33.10 \%, 63.90 \%$ and $3.00 \%$ of the respondents were belonged to their age group were $\leq 20$ years, 21-25 years and $\geq 26$ years respectively with mean age $21.55 \pm 1.93$ years of the respondents of public university compared to the respondents of private university $40.80 \%, 57.60 \%$ and $1.70 \%$ of the respondents were belonged to their age group were $\leq 20$ years, 21-25 years and $\geq 26$ years respectively with mean age $21.14 \pm 1.62$ years. It is found that $66.90 \%$ of the respondents were male students and $33.10 \%$ of the respondents were female students of public university on the other hand $62.80 \%$ of the respondents were male and $37.2 \%$ of the respondents were female students of private university. Study shows that $16.80 \%$, $22.30 \%, 24.20 \%, 20.10 \%$ and $16.50 \%$ of the students were $1^{\text {st }}$ year, $2^{\text {nd }}$ year, $3^{\text {rd }}$ year, $4^{\text {th }}$ year and post graduate and above respectively of the public university compare to private university $43.00 \%, 24.50 \%, 18.20 \%, 12.10 \%$ and $2.20 \%$ of the students were $1^{\text {st }}$ year, $2^{\text {nd }}$ year, $3^{\text {rd }}$ year, $4^{\text {th }}$ year and post graduate and above respectively.

Table II : Distribution of respondents by types of visual disorders $(n=726)$ (Multiple responses).

\begin{tabular}{lrrrr} 
Types of visual disorders & \multicolumn{2}{c}{$\begin{array}{c}\text { Public University } \\
\text { Frequency }\end{array}$} & \multicolumn{2}{c}{$\begin{array}{c}\text { Private University } \\
\text { Percentage }\end{array}$} \\
$\begin{array}{lrrrc}\text { Frequency } \\
\text { Percentage }\end{array}$ \\
Headache (Anterior aspect) & 102 & 28.10 & 133 & 36.60 \\
Dry eye syndrome & 36 & 9.90 & 35 & 9.60 \\
Eye strain or Fatigue & 65 & 17.90 & 80 & 22.00 \\
Burning & 39 & 10.70 & 46 & 12.70 \\
Itching & 24 & 6.60 & 43 & 11.80 \\
Tearing eyes & 82 & 22.60 & 115 & 31.70
\end{tabular}




$\begin{array}{lrrrr}\text { Irritated eyes } & 31 & 8.50 & 54 & 14.90 \\ \text { Squinting } & 2 & 0.60 & 20 & 5.50 \\ \text { Blurry vision } & 68 & 18.70 & 57 & 15.70 \\ \text { Double vision } & 10 & 2.80 & 25 & 6.90 \\ \text { Temporary change in color vision } 7 & 1.90 & 23 & 6.30 \\ \text { Trouble seeing at night } & 10 & 2.80 & 22 & 6.10 \\ \text { Distorted vision } & 2 & 0.60 & 3 & 0.80\end{array}$

Table II reveals that $28.10 \%, 9.90 \%, 17.90 \%, 10.70 \%, 6.60 \%$, $22.60 \%, 8.50 \%, 0.60 \%, 18.70 \%, 2.80 \%, 1.90 \%, 2.80 \%$ and $0.60 \%$ of the respondents of public university had complained headache, dry eye syndrome, eye strain, burning, itching, tearing eyes, irritated eyes, squinting, blurry vision, double vision, temporary change in color vision, trouble seeing at night, distorted vision respectively. On the other hand respondents of the private university $36.60 \%, 9.60 \%, 22.00 \%, 12.70 \%, 11.80 \%$, $31.70 \%, 14.90 \%, 5.50 \%, 15.70 \%, 6.90 \%, 6.30 \%, 6.10 \%$ and $0.80 \%$ had complained headache, dry eye syndrome, eye strain, burning, itching, tearing eyes, irritated eyes, squinting, blurry vision, double vision, temporary change in color vision, trouble seeing at night, distorted vision respectively.

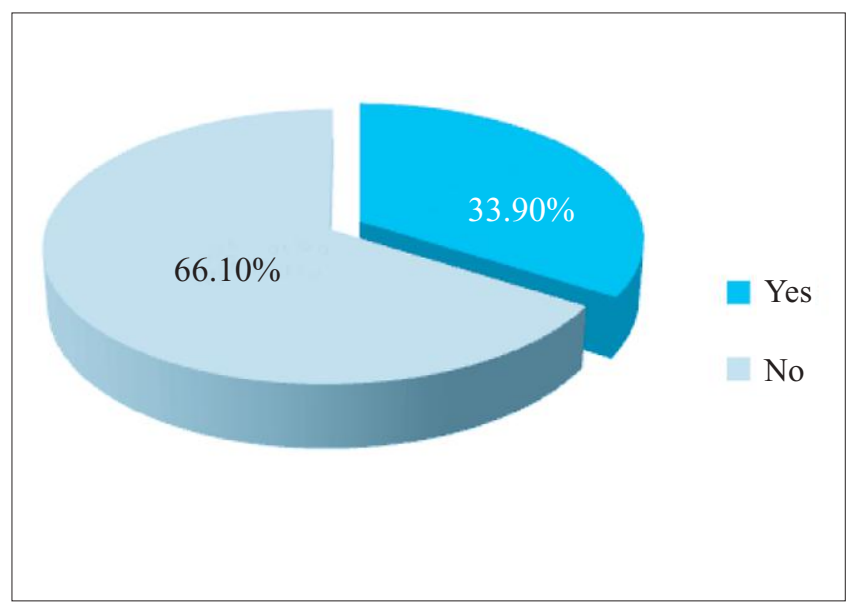

Figure 1: Distribution of respondents by use of goggles (Public University).

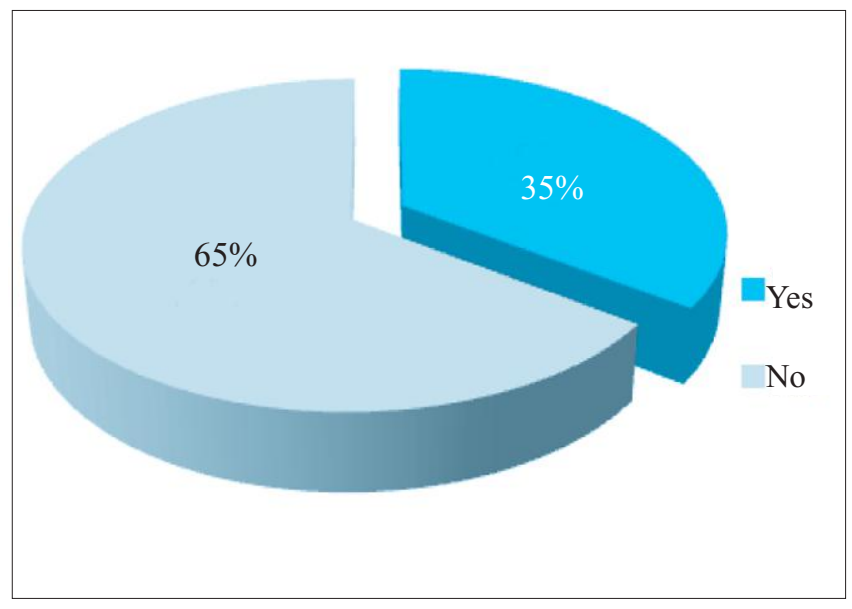

Figure 2 : Distribution of respondents by use of goggles (Private University).
Figure 1 reveals that $33.90 \%$ of the respondents of public university used goggles and $66.10 \%$ of the respondents did not use contrast to the respondents of private university figure 2 shows that $35.00 \%$ used goggles and $65.00 \%$ did not use.

Table III : Distribution of respondents by types of goggles $(n=726)$.

\begin{tabular}{|c|c|c|c|c|}
\hline \multirow[t]{2}{*}{ Types of goggles } & \multicolumn{2}{|c|}{ Public University } & \multicolumn{2}{|c|}{ Private University } \\
\hline & Frequency & Percentage & Frequency & Percentage \\
\hline Minus power & 118 & 32.50 & 117 & 32.20 \\
\hline Plus power & 4 & 1.10 & 8 & 2.20 \\
\hline Bifocal & 1 & 0.30 & 3 & 0.80 \\
\hline Total & 123 & 33.90 & 128 & 35.30 \\
\hline
\end{tabular}

It is found from Table III that $32.50 \%, 1.10 \%$ and $0.33 \%$ of the respondents of public university used goggles of minus power, plus power and bifocal respectively compared to the respondents of private university $32.20 \%, 2.20 \%$ and $0.80 \%$ used goggles of minus power, plus power and bifocal respectively.

Table IV : Association between uses of Twitter and eye strain of the respondents.

\begin{tabular}{|c|c|c|c|c|c|c|}
\hline \multirow[t]{2}{*}{ University } & \multirow{2}{*}{$\begin{array}{l}\text { Uses of } \\
\text { Twitter }\end{array}$} & \multicolumn{2}{|c|}{ Eye Strain } & \multirow[t]{2}{*}{ Total } & \multirow[t]{2}{*}{$\chi^{2}$} & \multirow[t]{2}{*}{ p-value } \\
\hline & & Yes & No & & & \\
\hline \multirow[t]{6}{*}{ Public } & Yes & $2(0.6)$ & $42(11.6)$ & $44(12.1)$ & 6.080 & 0.014 \\
\hline & No & $63(17.4)$ & $256(70.5)$ & $319(87.9)$ & & \\
\hline & Total & $65(17.9)$ & $298(82.1)$ & $363(100)$ & & \\
\hline & Yes & $22(6.1)$ & $61(16.8)$ & $83(22.9)$ & 1.250 & 0.264 \\
\hline & No & $58(16.0)$ & $222(61.2)$ & $280(77.1)$ & & \\
\hline & Total & $80(22.0)$ & $283(78.0)$ & $363(100)$ & & \\
\hline
\end{tabular}

Results were published as number (\%), $\chi^{2}$ test was performed and $\mathrm{p}<0.05$ was level of significance.

The Table IV shows that there were statistically significant association between uses of Twitter and eye strain of the respondents of public university $(p=0.014<0.05$ ) compared to the respondents of private university statistically no association between uses of Twitter and eyestrain of the respondents $(\mathrm{p}=0.264>0.05)$.

Table $\mathbf{V}$ : Distribution of the respondents by binary logistic regression of visual disorders with social media disorders.

\begin{tabular}{lllcc} 
University & Dependent Variables & Covariates & p-value & Exp(B)/ Odds \\
Public & Headache (Anterior aspect) & Social Media & 0.001 & 2.684 \\
& Dry eye syndrome & Disorders & 0.017 & 2.495 \\
& Eye strain & & 0.034 & 1.991 \\
& Burning & & 0.002 & 3.091 \\
& Blurry vision & & 0.001 & 3.025 \\
\multirow{5}{*}{ Private } & Trouble seeing at night & & 0.043 & 4.230 \\
& Eye strain & Social Media & 0.017 & 2.050 \\
& Tearing eyes & Disorders & 0.002 & 2.287 \\
& Double Vision & & 0.007 & 3.885 \\
\hline
\end{tabular}


Table V shows that social media disorders influence significantly on different types of visual disorders including headache $(\mathrm{p}=0.001$ and Odds $=2.684)$ dry eye syndrome $(\mathrm{P}=0.017$ and Odds $=2.495)$, eye strain $(\mathrm{p}=0.034$ and Odds $=1.99)$ burning $(\mathrm{p}=0.002$ and Odds $=3.091)$ blurry vision $(\mathrm{p}=0.001$ and Odds $=3.025)$ and trouble seeing at night $(p=0.043$ and Odds $=$ 4.230 ) of the respondents of public university. Compared to the respondents of private university social media disorders influence significantly on different types visual disorders including eyestrain $(p=0.017$ and Odds $=2.050)$, tearing eyes $(p=0.002$ and Odds $=2.287)$ and double vision $(p=0.007$ and Odds $=3.885$ ). These findings were statistically significant.

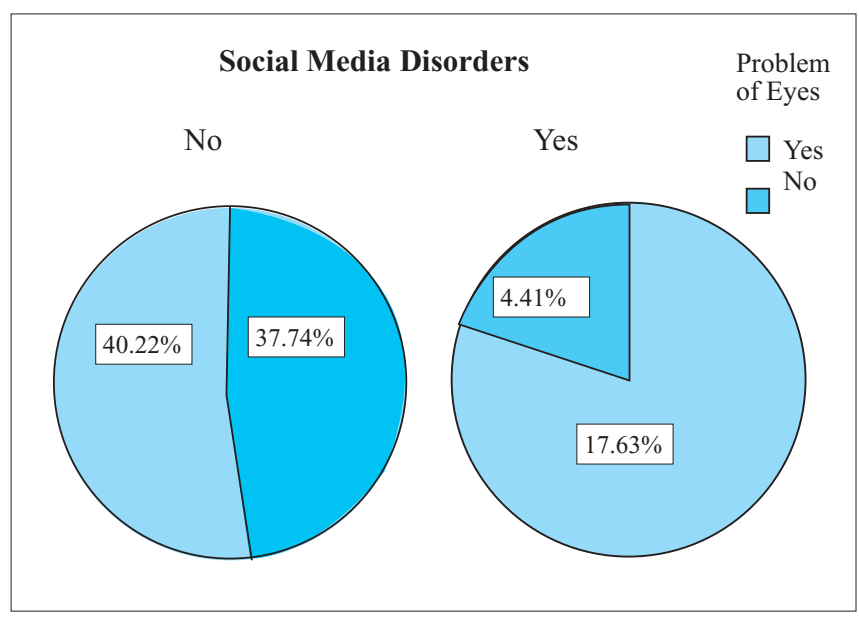

Figure 3 : Distribution of the respondents by social media disorders and problem of eye (Public university).

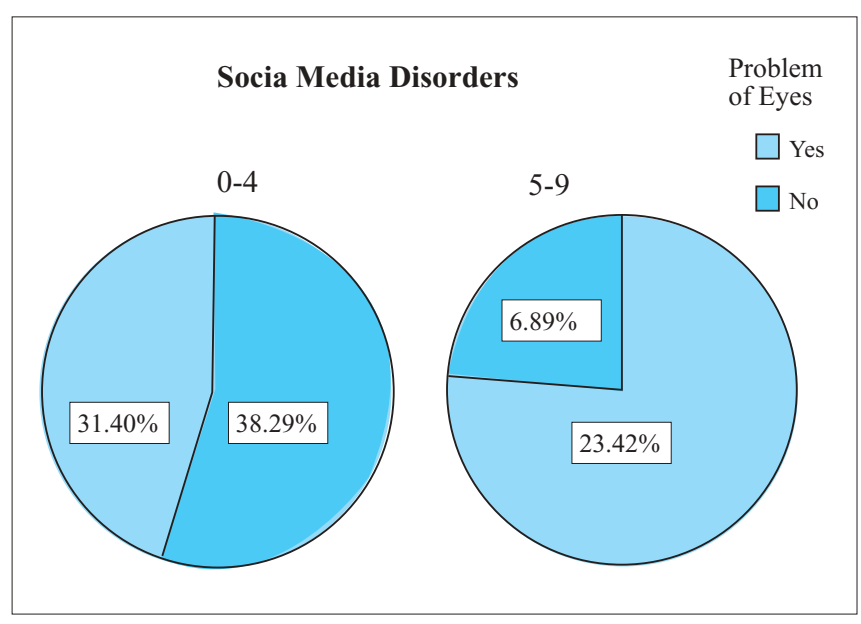

Figure 4 : Distribution of the respondents by social media disorders and problem of eye (Private university).

Figure 3 reveals that $17.63 \%$ of the respondents had social media disorders and they suffered eye problem and $4.41 \%$ of the respondent did not suffered eye problem. Whereas $37.74 \%$ of the respondents had no social media disorders but they had been suffering eye problems and $40.22 \%$ of the respondent did not suffered this disorders among the respondents of public university. Contrast to private university figure 4 shows that
$23.42 \%$ of the respondents had social media disorders and they suffered eye problem and $6.89 \%$ of the respondents did not suffered eye problem. Whereas $38.29 \%$ of the respondents had no social media disorders but they had been suffering eye problem and $31.40 \%$ of the respondent did not.

Table VI : Distribution of the respondents by Spearman's rank correlation of eye disorders with social media.

$\begin{array}{lllll}\text { University } & \text { Variables } & \text { Variables } & \text { r-value } & \text { p-value } \\ \text { Public } & \text { Viber } & \text { Squinting of eyes } & 0.106 & 0.044 \\ & \text { LinkedIn } & & 0.118 & 0.025 \\ & \text { Twitter } & \text { Temporary changes } & 0.132 & 0.012 \\ & \text { Imo } & \text { in color vision } & 0.157 & 0.003 \\ & \text { Ring ID } & \text { Double Vision } & 0.215 & 0.000 \\ \text { Private } & \text { YouTube } & \text { Headache } & 0.115 & 0.029 \\ & \text { LinkedIn } & \text { Burning } & 0.146 & 0.005 \\ & \text { LinkedIn } & \text { Tearing of eyes } & 0.114 & 0.029 \\ & \text { LinkedIn } & \text { Dry eye syndrome } & 0.140 & 0.008 \\ & \text { LinkedIn } & \text { Blurry vision } & 0.134 & 0.011 \\ & \text { LinkedIn } & \text { Temporary changes } & 0.144 & 0.006 \\ & & \text { in color vision } & & \\ & \text { Instagram } & \text { Double vision } & 0.106 & 0.044 \\ & \text { Vigo } & \text { Double vision } & 0.180 & 0.001 \\ & \text { Ring ID } & \text { Dry eye syndrome } & 0.144 & 0.006 \\ & \text { Distorted vision } & 0.140 & 0.008\end{array}$

p- value obtained from Spearman's rank correlation test.

Table VI finds that there were positive correlation Viber and LinkedIn with squinting $(p=0.044<0.05, p=0.025<0.05)$, Twitter and Imo with temporary changes in colour vision $(\mathrm{p}=$ $0.012<0.05, \mathrm{p}=0.003<0.05)$, Ring ID with double vision $(\mathrm{p}=$ $0.000<0.05$ ) of the respondents of public university. Compared to the respondents of private university there were positive correlation YouTube with headache $(\mathrm{p}=0.029<0.05)$. It was found that LinkedIn positively correlated with Burning $(p=0.005<0.05)$, Tearing of eyes $(p=0.029<0.05)$, Dry eye syndrome $(p=0.006<0.05)$, Blurry vision $(p=0.011<0.05)$, and Temporary changes in color vision $(p=0.006<0.05)$. Instagram positively correlated with double vision $(\mathrm{p}=0.044<0.05)$, Vigo positively correlated with double vision and dry eye syndrome $(\mathrm{p}=0.001<0.05, \mathrm{p}=0.006<0.05)$, Ring ID distorted vision $(\mathrm{p}=0.008<0.05)$ and these findings were statistically significant.

\section{DISCUSSION}

Study found that $28.10 \%, 9.90 \%, 17.90 \%, 10.70 \%, 6.60 \%$, $22.60 \%, 8.50 \%, 0.60 \%, 18.70 \%, 2.80 \%, 1.90 \%, 2.80 \%$ and $0.60 \%$ of the respondents of public University had complained headache, dry eye syndrome, eye strain, burning sensation, itching, tearing eyes, irritated eyes, squinting, blurring of vision, double vision, temporary change in color vision, trouble seeing at night, distorted vision respectively. These findings were nearly similar findings to the study conducted by Sa et al at Sao Paulo, Brazil ${ }^{9}$. On the other hand respondents of the private University $36.60 \%, 9.60 \%, 22.00 \%, 12.70 \%, 11.80 \%$, 
$31.70 \%, 14.90 \%, 5.50 \%, 15.70 \%, 6.90 \%, 6.30 \%, 6.10 \%$ and $0.80 \%$ had complained headache, dry eye syndrome, eye strain, burning, itching, tearing eyes, irritated eyes, squinting, blurry vision, double vision, temporary change in colour vision, trouble seeing at night, distorted vision respectively. Another similar finding of the study was done by Akinbinu and Mashalla in the year of $2014^{2}$.

There were statistically significant association between uses of Twitter and eye strain of the respondents of public university. This findings were similar type study was conducted by Alamri et al in the year of $2018^{12}$. Social media disorders influence significantly on headache, dry eye syndrome, burning, blurry vision and trouble seeing at night of the respondents of public university. This findings were closely similar findings to the study carried out by Ichhpujani et al in the year of $2019^{4}$. On the other hand, respondents of private university social media disorders influence significantly on tearing eyes and double vision. Another similar study was done by Greenwald and Blake $^{13}$. Social media disorders influence significantly on eyestrain of the students of both public and private universities. Findings of binary logistic regression were similar to the study conducted by Kawahara in the year of $2017^{5}$.
Social media positive correlation squinting, temporary changes in colour vision, double vision of the respondents of public university. Another similar type study conducted by Sa et al in the year of $2012^{9}$. Whereas Social media positive correlation with headache, burning, tearing of eyes, dry eye syndrome, blurry vision, temporary changes in color vision, double vision, dry eye syndrome, distorted vision of the respondents of private university. These findings were nearly similar findings to the study carried out by Sheppard and Wolffsohn ${ }^{1}$.

\section{CONCLUSION}

Study conclude that students of both public and private universities had been suffering dry eye syndrome, eye strain, burning, itching, tearing eyes, irritated eyes, squinting, blurry vision, double vision, temporary change in color vision, trouble seeing at night and distorted vision due to excessive use of social media.

\section{DISCLOSURE}

All the authors declared no competing interest.

\section{REFERENCES}

1. Sheppard AL and Wolffsohn JS. Digital Eye Strain: Prevalence, Measurement and Amelioration. BMJ Open Opthalmology. 2018; 3(1):01-10.

2. Akinbinu TR, Mashalla YJ. Impact of Computer Technology on Health: Computer Vision Syndrome (CVS). Medical Practice and Review. 2014:5(3):20-30

3. Kozeis N. Impact of Computer Use on Children's Vision. Hippokratia. 2009;13(4):230-231.

4. Ichhpujani P, Singh RB, Foulsham W, Thakur S, Lamba AS. Visual Implications of Digital Device in School Children: A Cross-Sectional Study. BMC Ophthalmology. 2019:76-79.

5. Kawahara JI. Effect of Presence of a Mobile phone During a Spatial Visual Search. Japanese Psychological Research, 2017;59(2):188-198.

6. Sadagopan AP, Manivel R, Marimuthu A, Nagaraj H, Ratnam K et al. Prevalence of Smart Phone Users at Risk For Developing Cell Phone Vision Syndrome among College Students. J Psychol Psychother. 2017;7(3):299-302.

7. Demirci S, Demirci K, Akgonul M. Headache in Smartphone Uzers: A cross-sectional Study. J Neurol Psychol. 2016; 4(1):01-05.

8. Shrivastava SR and Bobhate PS. Computer Related Health Problems among Software Professionals in Mumbai: A Cross-sectional Study. Int J Health Allied Sci. 2012;1(2):74-78.

9. Sa EC, Junior MF, Rocha LE. Risk Factors for Computer Visual Syndrome (CVS) among Operators of Two Call Centers in Sao Paulo, Brazil. Work. 2012;41:3568-3574.

10. Maples WC, Derosier W, Hoenes R, Bendure R. The effects of Cell Phone Use on Peripheral Vision. Optometry- Journal of the American Optometric Association. 2008;79(1):36-42.

11. Khan MM. Adverse Effects of Excessive Mobile Phone Use. Int J Occup Med Enviorn Health. 2008;21(4):289-293.

12. Alamri AA, Alhibshi N, Alnefaie M, Alzhrani W. Pattern of Digital Device Usage and Its Related Health Effects on Elementary and Middle School Students: An Instrument Development and Regression Analysis. Electronic Physician. 2018;10(10):7333-7340.

13. Greenwald MJ and Blake R. Long Lasting Visual effects from Viewing a Computer Vodeo display. New England Journal of Medicine. $1983 ; 309-315$. 